\title{
Formulasi Sediaan Hand Body Lotion Menggunakan Ekstrak Etanol Daging Buah Kedondong (Spondias dulcis Soland. ex Forst. fil.) Sebagai Pelembab Kulit
}

\author{
Sudewi, Yessi Febriani, Siti Raudah, Ira Nofriani, Nilsya Febrika Zebua* \\ Fakultas Farmasi, Program Studi Farmasi, Universitas Tjut Nyak Dhien, Medan, Indonesia \\ Email: 5,"nf.zebua@gmail.com
}

\begin{abstract}
Abstrak-Buah kedondong (Spondias dulcis Soland. ex Forst. fil.) merupakan tanaman buah yang berasal dari Asia Selatan dan Asia Tenggara dan tersebar di daerah tropis. Buah kedondong mengandung vitamin A, B dan C, karbohidrat, protein dan lemak. Penelitian ini bertujuan untuk mengetahui daging buah kedondong (Spondias dulcis Soland. ex Forst. fil.) dalam bentuk ekstrak etanol dapat diformulasikan ke dalam sediaan hand body lotion yang pada konsentrasi tertentu dapat memberikan efek melembabkan kulit dan tidak mengiritasi. Penelitian ini dilakukan dengan metode eksperimental, menggunakan bahan uji daging buah kedondong (Spondias dulcis Soland. ex Forst. fil.). Ekstrak etanol daging buah kedondong (Spondias dulcis Soland. ex Forst. fil.) diperoleh dengan cara maserasi menggunakan penyari etanol 96\%, kemudian dipekatkan dengan rotary evaporator. Sediaandiformulasikan ke dalam hand body lotion konsentrasi $0,5 \%, 1,5 \%, 2,5 \%$ dan 3,5\%, serta blanko. Pemeriksaan mutu fisik sediaan meliputi, uji homogenitas, uji $\mathrm{pH}$, uji tipe emulsi, uji stabilitas, uji iritasi dan uji efektitivitas sediaan dalam melembabkan kulit serta membandingkan dengan sediaanyang beredar di pasaran dengan menggunakan alat Skin Moisturer Checker (Aram ${ }^{\circledR}$ ) serta dilakukan pengolahan data secara statistik dengan program SPSS 26.00 metode ANOVA. Hasil penelitian menunjukkan bahwa daging buah kedondong (Spondias dulcis Soland. ex Forst. fil.) dalam bentuk ekstrak etanol dapat diformulasikan kedalam sediaan hand body lotion, merupakan sediaan yang homogen dengan tipe emulsi minyak dalam air (M/A), memiliki rentang $\mathrm{pH}$ sesaat setelah dibuat 6,6-7,3 dan $\mathrm{pH}$ setelah penyimpanan 12 minggu 6,3-7,0, uji efektivitas kelembaban sediaanpada konsentrasi 3,5\% (Formula E) memberikan kelembaban (32\%) dikategorikan "lembab" yang secara statistik menunjukkan perbedaan yang bermakna dengan hasil pembanding, ,sediaan hand body lotion yang dibuat tidak mengiritasi kulit.
\end{abstract}

Kata Kunci: Buah Kedondong; Ekstrak Etanol; Hand Body Lotion; Pelembab Kulit

\begin{abstract}
Kedondong fruit (Spondias dulcis Soland. Ex Forst. Fil.) Is a fruit plant originating from South and Southeast Asia and spread in tropical areas. Kedondong fruit contains vitamins A, B and C, carbohydrates, protein and fat. This study aims to determine the pulp of kedondong (Spondias dulcis Soland. Ex Forst. Fil.) In the form of ethanol extract which can be formulated into a hand body lotion which at certain concentrations can provide a moisturizing effect on the skin and is not irritating. This research was conducted using experimental methods, using the test material of the pulp of the kedondong fruit (Spondias dulcis Soland. Ex Forst. Fil.). The ethanol extract of kedondong pulp (Spondias dulcis Soland. Ex Forst. Fil.) Was obtained by maceration using $96 \%$ ethanol filter, then concentrated using a rotary evaporator. The preparation is formulated into a hand body lotion with a concentration of $0.5 \%, 1.5 \%, 2.5 \%$ and $3.5 \%$, as well as a blank. Examination of the physical quality of the preparation includes, homogeneity test, $\mathrm{pH}$ test, emulsion type test, stability test, irritation test and effectiveness test of the preparation in moisturizing the skin and comparing with preparations on the market using the Skin Moisturer Checker (Aram ${ }^{\circledR}$ ) and statistical data processing was carried out using the SPSS 26.00 ANOVA method. The results showed that the pulp of kedondong (Spondias dulcis Soland. Ex Forst. Fil.) In the form of ethanol extract can be formulated into a hand body lotion, a homogeneous preparation with the type of oil-in-water emulsion (M / A), has a momentary $\mathrm{pH}$ range. After making 6,6-7,3 and $\mathrm{pH}$ after 12 weeks of storage 6,3-7,0, the effectiveness test of moisture preparation at a concentration of $3.5 \%$ (Formula E) gave moisture (32\%) categorized as "moist" which was statistically showed a significant difference with the comparison results, the hand body lotion that was made did not irritate the skin.
\end{abstract}

Keywords: Kedondong Fruit; Ethanol Extract; Hand Body Lotion; Skin Moisturizer

\section{PENDAHULUAN}

Defenisi kosmetik adalah sediaan atau paduan bahan yang siap untuk digunakan pada bagian luar badan (epidermis, rambut, kuku, bibir dan organ kelamin bagian luar), gigi dan rongga mulut untuk membersihkan, menambah daya tarik, mengubah penampilan, melindungi supaya tetap dalam keadaan baik, memperbaiki bau badan tetapi tidak dimasukkan untuk mengobati atau menyembuhkan suatu penyakit (Maknawi, 2018).

Kulit merupakan salah satu organ tubuh yang berada pada bagian luar tubuh manusia. Organ ini merupakan organ yang bersentuhan langsung dengan lingkungan, kulit befungsi untuk melindungi jaringan terhadap kerusakan kimia dan fisik, terutama kerusakan mekanik dan terhadap masuknya mikroorganisme. Kulit dapat mempengaruhi penampilan dan kepribadian seorang dan menjadi ciri berbagai tanda kehidupan seperti ras, genetik, estetika, budaya dan bangsa. Kulit juga dapat menjadi indikator kesehatan (Sonny, 2017).

Sediaan kosmetika topikal yang dapat dengan mudah diaplikasikan pada seluruh tubuh antara lain hand body lotion. Hand body lotion merupakan sediaan emulsi yang diaplikasikan secara topikal. Emulsi yang digunakan pada kulit dapat berupa minyak dalam air (M/A) atau air dalam minyak (M/A) (Allen, dkk, 2014).

Pelembab bekerja dengan komposisi yang bersifat oklusif dan humektan seperti halnya komponen pada Natural Moisturizing Factor (NMF). Komposisi yang bersifat oklusif secara fisik memblokir kehilangan air dari permukaan kulit sedangkan komposisi yang bersifat humektan bekerja dengan menarik air ke dalam kulit. Kulit yang dijaga kelembabannya dapat mempertahankan diri terhadap kerusakan akibat proses penuaan (Warner and Boissy, 2000). 


\section{Journal of Pharmaceutical and Health Research}

Vol 2, No 2, Juni 2021, pp. 40-45

ISSN 2721-0715 (media online)

DOI 10.47065/jharma.v2i2.861

Pada penelitian oleh Piccioni dkk didapatkan bahwa pelembab yang mengandung antiinflamasi dan anti oksidan meningkatkan sekresi sebum dan hidrasi secara signifikan dimana didapatkan berkurangnya eritem pada subjek dan peningkatan kelembaban (Piccioni et al, 2017).

Salah satu contoh pemanfaatan bahan alami dalam pembuatan sediaan kosmetik hand body lotion adalah menggunakan buah kedondong (Spondias dulcis Soland. ex Forst. fil.). Buah kedondong (Spondias dulcis Soland. ex Forst. fil.) merupakan buah yang berpotensi sebagai sumber antioksidan dan bermanfaat bagi kesehatan manusia karena mengandung vitamin $\mathrm{C}$ dan senyawa-senyawa fitokimia. Ditinjau dari segi kandungan vitamin $\mathrm{C}$, kedondong termasuk salah satu buah-buahan yang kaya akan vitamin C. Vitamin C ditemukan dalam jumlah tinggi pada kedondong sebesar $30 \mathrm{mg}$ per $100 \mathrm{~g}$ lebih besar dibandingkan jeruk nipis yaitu sebanyak $27 \mathrm{mg}$ per $100 \mathrm{~g}$. Vitamin $\mathrm{C}$ berfungsi sebagai antioksidan yang kuat dapat melindungi sel dari agen-agen penyebab kanker, dan esensial untuk biosintesa kolagen (Rakhmawati, 2015).

Buah kedondong sangat baik untuk membakar lemak, meningkatkan daya tahan tubuh, menjaga kesehatan kulit, mencegah demam, mencegah naiknya gula darah serta mampu menangkal radikal bebas penyebab kanker. Serat dalam kedondodng sangat baik mengikat lemak dan zat-zat berbahaya di dalam saluran cerna. Kedondong juga mencegah sembelit dan kanker kolon. Namun demikian, citarasa asam yang tinggi tidak dianjurkan untuk penderita maag dan tifus (Sutomo, 2016).

Pohon buah ini tidak kenal musim, karenanya tidak pernah kosong di pasar. Bentuk buahnya yang lonjong, mulai dipanen tidak saat masak atau matang di pohon. Ketika kulit buahnya berwarna hijau, yang menandakan masih muda, sudah bisa dimakan sebagai buah potong di hidangan rujak atau diolah menjadi asinan. Saat kulit buahnya berwarna kekuningan da mudah dikupas, menandakan buah ini masak dan rasanya manis (Putri, 2012).

Kedondong paling sering digunakan sebagai sumber makanan. Di Jawa Barat, daunnya yang muda digunakan sebagai bumbu untuk pepes. Di Costa Rica, daunnya juga dimakan sebagai salad hijau. Namun paling sering dikonsumsi adalah buahnya. Buah kedondong mngandung protein, lemak, karbohidrat, kasium, fosfor, zat besi, vitamin A, vitamin B1, vitamin C (Putri, 2012).

\section{METODOLOGI PENELITIAN}

\subsection{Alat-Alat}

Alat-alat yang digunakan dalam penelitian ini adalah timbangan digital (AND HT-120 ${ }^{\circledR}$ ), Lemari pengering, Blender $\left(\right.$ Philips $\left.^{\circledR}\right)$, Rotary Evaporator $\left(\right.$ E-scientific $\left.^{\circledR}\right)$, pH Meter $\left(\right.$ ATC $\left.^{\circledR}\right)$, Skin Moisture Checker (Aram ${ }^{\circledR}$ ) dan alat-alat gelas laboratorium $\left(\right.$ Pyrex $\left.^{\circledR}\right)$

\subsection{Bahan-bahan}

Buah kedondong (Spondias dulcis Soland. ex Forst. fil.), Etanol 96\%, Asam Stearat, Setil Alkohol, Nipasol, Nipagin, TEA, Parfum, larutan $\mathrm{pH}$ asam, larutan $\mathrm{pH}$ basa, Akuades.

\subsection{Pembuatan Simplisia Daging Buah Kedondong}

Sebanyak $11 \mathrm{~kg}$ buah kedondong (Spondias dulcis Soland. ex Forst. fil.) dikupas kulitnya, kemudian dicuci menggunakan akuades, ditiriskan, diiris tipis dan dikeringkan di dalam lemari pengering selama 3 kali 24 jam pada suhu $40^{\circ} \mathrm{C}$ sampai kering. Selanjutnya dihaluskan dengan menggunakan blender dan diperoleh serbuk daging buah kedondong (Spondias dulcis Soland. ex Forst. fil.), kemudian disimpan dalam wadah yang kering dan tertutup baik.

\subsection{Formula modifikasi hand body lotion}

Formula dasar hand body lotion yang dibuat berupa modifikasi yaitu tidak menggunakan gliserin, adeps lanae dan menggunakan parfum lemon.

$\begin{array}{llc}\text { R/ } & & 3 \\ \text { Asam stearat } & & 1 \\ \text { Ekstil alkohol } & \text { X } & \\ \text { Nipasol } & 0,10 & \\ \text { Nipagin } & 0,15 & \\ \text { Trietanolamin } & & 0,75 \\ \text { Parfum lemon } & & \mathrm{qs} \\ \text { Akuades } & 100 & \end{array}$

Keterangan:

$\mathrm{x}$ : ekstrak etanol buah kedondong

Cara Pembuatan hand body lotion dalam cawan penguap dimasukkan Asam stearat, Setil alkohol, kemudian dileburkan di atas penangas air sampai meleleh sempurna diperoleh Massa (I). Kemudian dalam beaker glass dimasukkan Nipasol, Nipagin, dan TEA dilarutkan dalam akuades panas, diperoleh Massa (II). Kedalam mortir panas dimasukkan bagian Massa I dan Massa II sambil digerus secara konstan stabil hingga homogen, maka diperoleh dasar 


\section{Journal of Pharmaceutical and Health Research}

Vol 2, No 2, Juni 2021, pp. 40-45

ISSN 2721-0715 (media online)

DOI 10.47065/jharma.v2i2.861

hand body lotion. Kemudian ditambahkan ekstrak etanol daging buah kedondong dalam berbagai konsentrasi sehingga diperoleh hand body lotion ekstrak etanol daging buah kedondong (Syeni, 2010).

\subsection{Pemeriksaan Mutu Fisik Sediaan}

Pemeriksaan mutu fisik sediaan hand body lotion meliputi uji homogenitas, uji $\mathrm{pH}$ sediaan, penentuan tipe emulsi, uji stabilitas sediaan, kemudian uji iritasi , uji efektivitas kelembaban serta membandingkan hand body lotion yang beredar di pasaran dengan menggunakan alat Skin Moisture Checker $\left(\right.$ Aram $\left.^{\circledR}\right)$.

\section{HASIL DAN PEMBAHASAN}

\subsection{Hasil pengujian homogenitas}

Uji homogenitas yang dilakukan pada sediaan hand body lotion yang diformulasikan menggunakan ekstrak etanol daging buah kedondong (Spondias dulcis Soland. ex Forst. fil.) dalam berbagai kosentrasi yaitu 0,5\%, 1,5\%, 2,5\% dan $3,5 \%$ serta sediaan blanko. Tidak terdapat butiran-butiran pada object glass yang dioleskan dengan sediaan hand body lotion ekstrak etanol buah kedondong (Spondias dulcis Soland. ex Forst. fil.) memenuhi syarat homogenitas sediaan hand body lotion ekstrak etanol buah kedondong (Spondias dulcis Soland. ex Forst. fil.).

\subsection{Hasil uji pH}

Penentuan $\mathrm{pH}$ sediaan hand body lotion pelembab ditentukan dengan $\mathrm{pH}$ meter. Data hasil pengukuran $\mathrm{pH}$ sediaan hand body lotion sesaat selesai dibuat dan data pengukuran $\mathrm{pH}$ penyimpanan 12 minggu dapat dilihat pada Tabel 1.

Tabel 1. Data Hasil Pengukuran pH Sediaan Hand Body Lotion Sesaat Selesai dibuat dan Data Pengukuran pH Selama Penyimpanan 12 Minggu.

\begin{tabular}{cccc}
\hline Formula & $\begin{array}{c}\mathrm{pH} \text { rata-rata pada } \\
\text { saat setelah di buat }\end{array}$ & $\begin{array}{c}\mathrm{pH} \text { rata-rata } \\
\text { penyimpanan 12 minggu }\end{array}$ & $\begin{array}{c}\text { Penurunan } \mathrm{pH} \\
(\%)\end{array}$ \\
\hline $\mathrm{A}$ & 7,4 & 7,1 & 4,0 \\
$\mathrm{~B}$ & 7,3 & 7,0 & 4,1 \\
$\mathrm{C}$ & 7,1 & 6,8 & 4,2 \\
$\mathrm{D}$ & 6,8 & 6,7 & 1,4 \\
$\mathrm{E}$ & 6,6 & 6,3 & 4,5 \\
\hline
\end{tabular}

\section{Keterangan}

HBLEEBK : : Hand Body Lotion Ekstrak Etanol Daging Buah Kedondong

Formula A : Blanko

Formula B : HBLEEBK $0,5 \%$

Formula $\mathrm{C} \quad$ : HBLEEBK $1,5 \%$

Formula D : HBLEEBK $2,5 \%$

Formula E : HBLEEBK $3,5 \%$

Rumus perhitungan persentase penurunan $\mathrm{pH}$, sebagai berikut : $=\frac{\text { Rata }- \text { rata sesaat dibuat }(-) \text { rata-rata penyimpanan } 12 \mathrm{minggu}}{} \times 100 \%$

Rata-rata sesaat dibuat

Berdasarkan data pada Tabel 1 di atas menunjukkan bahwa sediaan, mempunyai rentang pH tanpa blanko sesaat setelah dibuat 6,6-7,3 dan mempunyai rentang $\mathrm{pH}$ selama12 minggu penyimpanan 6,3-7,0. Hal ini menunjukkan bahwa Sediaan hand body lotion ekstrak etanol daging buah kedondong (Spondias dulcis Soland. ex Forst. fil.) mempunyai $\mathrm{pH}$ sesuai dengan $\mathrm{pH}$ kulit yaitu antara 4,5-7,5. Pada Tabel 1 menunjukkan bahwa semakin tinggi konsentrasi ekstrak etanol daging buah kedondong (Spondias dulcis Soland. ex Forst. fil.) yang ditambahkan ke dalam sediaan hand body lotion, maka $\mathrm{pH}$ semakin menurun. Ini dapat disebabkan karena banyaknya kandungan asam pada ekstrak etanol daging buah kedondong.

\subsection{Hasil uji tipe emulsi}

Penetapan tipe emulsi sediaan dapat dilakukan dengan menggunakan metil biru, jika metil biru terlarut saat diaduk dengan sediaan maka tipe emulsi sediaan tersebut adalah tipe emulsi minyak dalam air (M/A) (Ester, 2012). Data hasil penentuan tipe emulsi sediaan dapat dilihat pada Tabel 2.

Tabel 2. Data Hasil Penentuan Tipe Emulsi Sediaan

\begin{tabular}{ccc}
\hline \multirow{2}{*}{ Formulasi } & \multicolumn{3}{c}{ Kelarutan metil biru pada sediaan HBLEEBK } \\
\cline { 2 - 3 } & Larut & Tidak larut \\
A & $\sqrt{ }$ & - \\
B & $\sqrt{ }$ & - \\
C & $\sqrt{ }$
\end{tabular}


Journal of Pharmaceutical and Health Research

Vol 2, No 2, Juni 2021, pp. 40-45

ISSN 2721-0715 (media online)

DOI 10.47065/jharma.v2i2.861

\begin{tabular}{lll}
$\mathrm{D}$ & $\sqrt{ }$ & - \\
$\mathrm{E}$ & $\sqrt{ }$ & - \\
\hline
\end{tabular}

\author{
Keterangan \\ HBLEEBK \\ Formula A \\ : Hand Body Lotion Ekstrak Etanol Daging Buah Kedondong \\ Formula B \\ : Blanko \\ Formula C \\ : HBLEEBK 0,5\% \\ Formula D \\ : HBLEEBK $1,5 \%$ \\ Formula E \\ : HBLEEBK $2,5 \%$ \\ $\sqrt{ }$ \\ : HBLEEBK $3,5 \%$ \\ : Larut \\ : Tidak larut
}

Berdasarkan data pada Tabel 2 di atas menunjukkan bahwa sediaan hand body lotion buah kedondong (Spondias dulcis Soland. ex Forst. fil.) merupakan sediaan homogen karena metil biru dapat larut sempurna dalam sediaan hand body lotion pelembab ekstrak etanol daging buah kedondong (Spondias dulcis Soland. ex Forst. fil.) dalam berbagai konsentrasi yang berarti seluruh hand body lotion ekstrak etanol buah kedondong (Spondias dulcis Soland. ex Forst. fil.) mempunyai tipe emulsi minyak dalam air (M/A).

\title{
3.4 Hasil uji stabilitas sediaan
}

Hasil pengamatan kestabilan sediaan dilakukan selama 12 minggu. Data pengamatan kestabilan sediaan sesaat selesai dibuat hingga 12 minggu penyimpanan dapat dilihat pada Tabel 3.

Tabel 3. Data Pengamatan Kestabilan Sediaan

\begin{tabular}{|c|c|c|c|c|c|c|c|c|c|c|c|c|c|c|c|}
\hline \multirow{3}{*}{ Formula } & \multicolumn{12}{|c|}{ Pengamatan Selama Penyimpanan } & & & \\
\hline & \multicolumn{3}{|c|}{$\begin{array}{l}\text { Sesaat } \\
\text { Setelah } \\
\text { Dibuat }\end{array}$} & \multicolumn{3}{|c|}{$\begin{array}{c}\text { Setelah } 1 \\
\text { Minggu }\end{array}$} & \multicolumn{3}{|c|}{$\begin{array}{c}\text { Setelah } 4 \\
\text { Minggu }\end{array}$} & \multicolumn{3}{|c|}{$\begin{array}{c}\text { Setelah } 8 \\
\text { Minggu }\end{array}$} & \multicolumn{3}{|c|}{$\begin{array}{c}\text { Setelah } 12 \\
\text { Minggu }\end{array}$} \\
\hline & $\mathrm{X}$ & $\mathrm{y}$ & $\mathrm{Z}$ & $\mathrm{X}$ & $\mathrm{y}$ & $\mathrm{Z}$ & $\mathrm{X}$ & $\mathrm{y}$ & Z & $\mathrm{x}$ & $y$ & $\mathrm{Z}$ & $\mathrm{X}$ & $\mathrm{y}$ & Z \\
\hline A & - & - & - & - & - & - & - & - & - & - & - & - & - & - & - \\
\hline $\mathrm{B}$ & - & - & - & - & - & - & - & - & - & - & - & - & - & - & - \\
\hline $\mathrm{C}$ & - & - & - & - & - & - & - & - & - & - & - & - & - & - & - \\
\hline $\mathrm{D}$ & - & - & - & - & - & - & - & - & - & - & - & - & - & - & - \\
\hline $\mathrm{E}$ & - & - & - & - & - & - & - & - & - & - & - & - & - & - & - \\
\hline
\end{tabular}

$\begin{array}{ll}\text { Keterangan } & \\ \text { HBLEEBK } & : \text { Hand Body Lotion Ekstrak Etanol Daging Buah Kedondong } \\ \text { Formula A } & \text { : Blanko } \\ \text { Formula B } & : \text { HBLEEBK } 0,5 \% \\ \text { Formula C } & \text { : HBLEEBK 1,5\% } \\ \text { Formula D } & \text { : HBLEEBK 2,5\% } \\ \text { Formula E } & \text { : HBLEEBK 3,5\% } \\ \mathrm{x} & : \text { Perubahan warna } \\ \mathrm{y} & \text { : Perubahan bau } \\ \mathrm{z} & : \text { Pemisahan fase } \\ - & : \text { Tidak terjadi perubahan } \\ + & : \text { Terjadi perubahan }\end{array}$

Berdasarkan data pada Tabel 4 diatas menunjukkan bahwa, seluruh formula yang telah diamati tidak terjadi perubahan bau, perubahan fase dan perubahan warna selama 12 minggu penyimpanan. Hal ini menunjukkan bahwa hand body lotion ekstrak etanol daging buah kedondong (Spondias dulcis Soland. ex Forst. fil.) stabil dalam penyimpanan selama 12 minggu. Stabilitas dari suatu sediaan farmasi dapat dilihat dari ada tidaknya perubahan warna, bau selama penyimpanan. Perubahan-perubahan tersebut terjadi jika perubahan-perubahan yang terdapat dalam sediaan tersebut teroksidasi.

\subsection{Hasil Uji Iritasi terhadap Sukarelawan}

Hasil uji iritasi terhadap sukarelawan yang di oleskan sediaan hand body lotion pada kulit yang tipis bagian belakang telinga dan dibiarkan selama 24 jam. Data uji iritasi terhadap kulit sukarelawan dapat dilihat pada Tabel 4.

Tabel 4. Data Uji Iritasi terhadap Kulit Sukarelawan

\begin{tabular}{|c|c|c|c|c|}
\hline \multirow{2}{*}{ Formula } & \multirow{2}{*}{ Sukarelawan } & \multicolumn{3}{|c|}{ Pengamatan Iritasi pada Kulit } \\
\hline & & Kemerahan & Gatal-Gatal & Kulit Kasar \\
\hline
\end{tabular}


Vol 2, No 2, Juni 2021, pp. 40-45

ISSN 2721-0715 (media online)

DOI 10.47065/jharma.v2i2.861

\begin{tabular}{lllll}
\hline A & 1 & - & - & - \\
B & 2 & - & - & - \\
C & 3 & - & - & - \\
D & 4 & - & - & - \\
E & 5 & - & - & - \\
A & 6 & - & - & - \\
B & 7 & - & - & - \\
C & 8 & - & - & - \\
D & 9 & - & - & - \\
E & 10 & - & - & \\
\hline
\end{tabular}

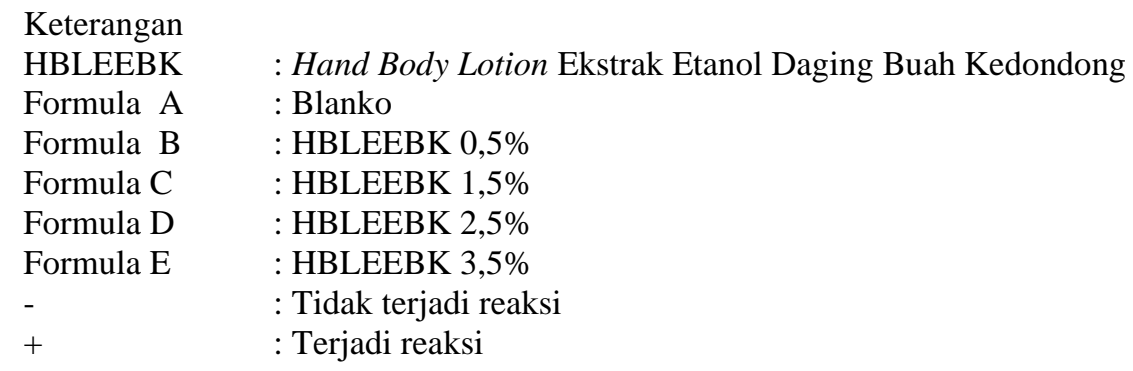

Berdasarkan data pada Tabel 4 di atas menunjukkan bahwa, tidak terlihat efek samping berupa kemerahan, gatal, dan pengkasaran yang ditimbulkan oleh sediaan hand body lotion yang dioleskan. Hal ini menunjukkan bahwa hand body lotion ekstrak etanol daging buah kedondong (Spondias dulcis Soland. ex Forst. fil.) tidak menyebabkan iritasi pada kulit sukarelawan.

\subsection{Hasil Uji Efektivitas Kelembaban}

Hasil uji efektivitas kelembaban menggunakan Skin Moisture Checker (Aram ${ }^{\circledR}$ ). Alat menunjukkan hasil dalam persen (\%). Data uji efektivitas kelembaban sediaan hand body lotion dan pembanding hand body lotion yang ada di pasaran dapat dilihat pada Tabel 5.

Tabel 5. Data Uji Efektivitas Kelembaban Sediaan Hand Body Lotion dan Pembanding Hand Body Lotion yang

\begin{tabular}{|c|c|c|c|c|c|c|c|c|}
\hline \multirow[b]{2}{*}{ No } & \multirow[b]{2}{*}{ Formula } & \multirow[b]{2}{*}{$\begin{array}{c}\text { Suka } \\
\text { Relawan }\end{array}$} & \multirow[b]{2}{*}{ Sebelum } & \multicolumn{4}{|c|}{ Minggu $\mathrm{Ke}(\%)$} & \multirow[b]{2}{*}{$\begin{array}{c}\% \\
\text { Pemulih } \\
\text { an }\end{array}$} \\
\hline & & & & $\mathrm{I}$ & II & III & IV & \\
\hline \multirow{3}{*}{1} & \multirow{3}{*}{ A } & 1 & $19 \%$ & $20 \%$ & $20 \%$ & $21 \%$ & $22 \%$ & $15,7 \%$ \\
\hline & & 2 & $20 \%$ & $20 \%$ & $21 \%$ & $22 \%$ & $22 \%$ & $10 \%$ \\
\hline & & 3 & $20 \%$ & $21 \%$ & $21 \%$ & $22 \%$ & $22 \%$ & $10 \%$ \\
\hline \multirow{5}{*}{2} & \multirow{5}{*}{$\mathrm{B}$} & Mean & $19,7 \%$ & $20,3 \%$ & $20,7 \%$ & $21,7 \%$ & $22 \%$ & $11,9 \%$ \\
\hline & & 1 & $20 \%$ & $21 \%$ & $21 \%$ & $22 \%$ & $23 \%$ & $15 \%$ \\
\hline & & 2 & $20 \%$ & $20 \%$ & $21 \%$ & $22 \%$ & $23 \%$ & $15 \%$ \\
\hline & & 3 & $20 \%$ & $21 \%$ & $22 \%$ & $22 \%$ & $23 \%$ & $15 \%$ \\
\hline & & Mean & $20 \%$ & $20,7 \%$ & $21,3 \%$ & $22 \%$ & $23 \%$ & $15 \%$ \\
\hline \multirow{3}{*}{3} & \multirow{3}{*}{$\mathrm{C}$} & 1 & $22 \%$ & $24 \%$ & $27 \%$ & $29 \%$ & $30 \%$ & $36,3 \%$ \\
\hline & & 2 & $22 \%$ & $24 \%$ & $27 \%$ & $29 \%$ & $30 \%$ & $36,3 \%$ \\
\hline & & 3 & $22 \%$ & $24 \%$ & $27 \%$ & $29 \%$ & $30 \%$ & $36,3 \%$ \\
\hline \multirow{6}{*}{4} & \multirow{6}{*}{$\mathrm{D}$} & Mean & $22 \%$ & $24 \%$ & $27 \%$ & $29 \%$ & $30 \%$ & $36,3 \%$ \\
\hline & & 1 & $26 \%$ & $28 \%$ & $29 \%$ & $31 \%$ & $31 \%$ & $19,2 \%$ \\
\hline & & 2 & $26 \%$ & $28 \%$ & $29 \%$ & $31 \%$ & $32 \%$ & $23 \%$ \\
\hline & & 3 & $26 \%$ & $28 \%$ & $29 \%$ & $31 \%$ & $32 \%$ & $23 \%$ \\
\hline & & Mean & $26 \%$ & $28 \%$ & $29 \%$ & $31 \%$ & $31,7 \%$ & $21,7 \%$ \\
\hline & & 1 & $28 \%$ & $29 \%$ & $29 \%$ & $30 \%$ & $32 \%$ & $14,2 \%$ \\
\hline
\end{tabular}


Journal of Pharmaceutical and Health Research

Vol 2, No 2, Juni 2021, pp. 40-45

ISSN 2721-0715 (media online)

DOI 10.47065/jharma.v2i2.861

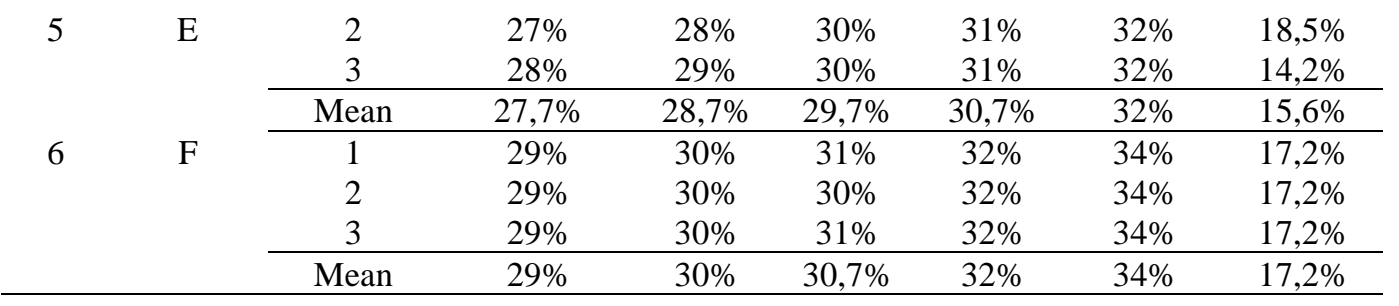

$\begin{array}{ll}\text { Keterangan } & \\ \text { HBLEEBK } & \text { : Hand Body Lotion Ekstrak Etanol Daging Buah Kedondong } \\ \text { Formula A } & \text { : Blanko } \\ \text { Formula B } & \text { : HBLEEBK 0,5\% } \\ \text { Formula C } & \text { : HBLEEBK 1,5\% } \\ \text { Formula D } & \text { : HBLEEBK 2,5\% } \\ \text { Formula E } & \text { : HBLEEBK 3,5\% } \\ \text { Formula F } & \text { : Hand Body Lotion pembanding di pasaran (Marina) } \\ \text { Dehidrasi } & \text { : Bila 0-29 \% } \\ \text { Lembab } & \text { : Bila 30-50\% } \\ \text { Hidrasi } & \text { : Bila 51-100\% }\end{array}$

Berdasarkan data pada Tabel 5 diatas menunjukkan bahwa formula E yaitu hand body lotion EEBK dengan konsentrasi 3,5\% memiliki kelembaban 32\% pada minggu ke-4 yang mana hampir mendekati hasil dari hand body lotion pembanding di pasaran (Marina). Pemakaian hand body lotion ekstrak etanol daging buah kedondong (Spondias dulcis Soland. ex Forst. fil.) memberikan efek terhadap kelembaban kulit setelah menggunakan hand body lotion selama empat minggu perawatan dan kelembaban kulit semakin meningkat.

\section{KESIMPULAN}

Berdasarkan hasil penelitian terhadap bahan uji daging buah kedondong (Spondias dulcis Soland. ex Forst. fil.) dapat disimpulkan daging buah kedondong (Spondias dulcis Soland. ex Forst. fil.) dalam bentuk ekstrak etanol dapat diformulasikan ke dalam sediaan hand bod lotion pelembab yang stabil. Merupakan sediaan yang homogen dengan tipe emulsi minyak dalam air (M/A), merupakan sediaan yang stabil, mempunyai rentang $\mathrm{pH}$ tanpa blanko pada saat selesai dibuat 6,6-7,3 dan rentang $\mathrm{pH}$ 6,3-7,0 setelah penyimpanan 12 minggu. Hand body lotion ekstrak etanol daging buah kedondong (Spondias dulcis Soland. ex Forst. fil.) pada konsentarasi 3,5\% (Formula E) memiliki pemulihan kelembaban terbaik memberikan kelembaban dalam kategori "lembab" (32\%) pada minggu ke-4 yang secara statistik menunjukkan perbedaan yang bermakna, mendekati hasil yang hampir sama dengan hand body lotion pembanding (Marina) yang memberikan kelembaban dalam kategori "lembab" (34\%). Sediaan hand body lotion ekstrak etanol daging buah kedondong (Spondias dulcis Soland. ex Forst. fil.) yang diteliti tidak mengiritasi kulit.

\section{DAFTAR PUSTAKA}

Maknawi.(2018). Pengertian Kosmetik Sejarah dan Penggolongan diakses dari (https://Maknawi.net//pengertian-kosmetiksejarahdanpenggolongannya/) 01 April 2019. Halaman 7-9.

Sonny J.R. Kalangi, (2017). HistofisiologiKulit. Manado: Universitas Sam Ratulangi Manado. Halaman 12-20.

Allen, L.V., Popovich, N.G., Ansel, H.C., (2014), Ansel Bentuk Sediaan Famasetis \& Sistem Penghantaran Obat. Edisi 9. Jakarta: Penerbit Buku Kedokteran EGC. Halaman 128.

Warner, R. R. \& Boissy, Y. L. (2000). Effect of Moisturizing Product on the Structure of Lipid in the Outer Stratum Corneum of Human. Journal. In: LODEN, M. \& MAIBACH, H. I. (eds.) Dry Skin and Moisturizer, Chemistry and Function. Boca Raton, London, New York, Washington, DC. CRC Press. Halaman 212.

Piccioni, A., García-Rodrigo, C. G., Pellegrini, C., Mazzocchetti G. \& Fargnoli, M. C. (2017). Improving Skin Aging, Skin Hydration and Sensitive Skin with Four Specific Skin Care Products. Journal. Results from a Single-Centre, Observational, Prospective Study. J of Cosm, Dermatol Scie App, 7, 48-56.

Rakhmawati, R. (2015). Pengaruh Proporsi Buah: Air dan Lama Pemanasan Terhadap Aktivitas Antioksidan Sari Buah Kedondong (Spondias dulcis). Malang: Jurnal. Jurusan Teknologi Hasil Pertanian, FTP Universitas Brawijaya Malang. Halaman 1683.

Sutomo, B. (2016). 378 Resep Jus \& Ramuan Herbal. Depok: PT. Kawan Pustaka. Halaman 32.

Putri. (2012). Pemanfaatan Sirup Glukosa Hidrolisa Selulosa dari Kulit Buah Kedondong (Spondias dulcis) yang Dimanfaatkan Sebagai Pemanis pada Pembuatan Manisan dari Buah Lengkeng (Nephelium longanum). Skripsi. Medan: Fakultas Matematika dan Ilmu Pengetahuan Universitas Sumatera Utara. Halaman 5-7.

Syeni, B. A. (2010). Aplikasi Keraginan dalam Pembuatan Skin Lotion. Skripsi. Bogor:Departemen Teknologi Hasil Perairan Fakultas Perikanan dan Ilmu Pengetahuan Institut Pertanian Bogor. Halaman 75.

Ester. (2012). Formulasi Gel dari Ekstrak Rimpang. Skripsi. Medan: Universitas Sumatera Utara. Vol 1. Halaman 12. 